\title{
Indoor Environmental Quality Assessment of Historic Buildings in the State Park: A Case Study in Michigan
}

\author{
Suk-Kyung Kim ${ }^{1}$ \\ ${ }^{1}$ Inteiror Design Program, School of Planning, Design, \& Construction, Michigan State University, USA \\ Correspondence: Suk-Kyung Kim, School of Planning, Design, \& Construction, Michigan State University, East \\ Lansing, MI 48824, USA. Tel: 1-517-353-9167. E-mail: kimsk@msu.edu
}

Received: November 9, 2016

Accepted: August 17, $2018 \quad$ Online Published: September 28, 2018

doi:10.5539/jsd.v11n5p263

URL: https://doi.org/10.5539/jsd.v11n5p263

\begin{abstract}
Michigan State University and the Michigan Department of Natural Resources established a partnership for sustainable park planning in October 2011. The purpose of the partnership was to enable students in the design fields to work on real-world projects and provide practical solutions. One of the notable projects was to assess old historic buildings in one state park and propose renovation plan to improve its indoor environmental quality and energy efficiency. The buildings in the park functioned as the traveler's destination in the 1920s and still preserve original interior and exterior features.

The team of undergraduates and faculty in interior design visited the park and assessed the interior and exterior conditions of two of its buildings. They used an assessment tool which was designed on a basis of the elements in the indoor environmental quality category (IEQ) of the US Green Building Council's LEED. Results revealed that the indoor environmental conditions of the buildings should be improved. The energy efficiency of the buildings was low. Based on this assessment, this study offered practical suggestions for improving the building's indoor environmental quality. This study also proposed an assessment tool for the historic buildings in the state parks in Michigan to assess current indoor environmental quality of those buildings.
\end{abstract}

Keywords: state parks, buildings in the state parks, indoor environmental quality

\section{Introduction}

\subsection{Background}

The mission of the Department of Natural Resources (DNR) in the State of Michigan has been protecting natural and cultural resources, ensuring sustainable recreation use, and improving and developing strong relationships and partnerships with various stakeholders since the department was established in the 1920s (DNR, 2016). One of the notable recent efforts was to improve sustainability of the parks through establishing strong partnerships with local communities. The first discussion between the DNR and Michigan State University was initiated in the fall of 2011 to enhance this effort through establishing a strong partnership between DNR and the School of Planning, Design, \& Construction that had students and faculty in landscape architecture, interior design, urban and regional planning, and construction management. The team of several School faculty and DNR staff reviewed the problems associated with the physical conditions and established a timeline to improve them. They also formulated building management strategies for the state parks and their buildings located in those parks.

\subsection{Research Need and Goals}

The first phase of this partnership was to identify several key locations of the state parks of which physical condition and management strategies needed improvement. The first target of this sustainable park planning project was located in Brooklyn in Michigan. This park had been known as a very popular stop for travelers since the 1800s through the 1920s. This park has two main buildings, referred to as Walker Tavern building and Hewitt House building. Walker Tavern building was a popular travelers' destination since it was famous for its dinner menu and antiques (Quinn Evans Architects, 2003).

These two main buildings and other auxiliary buildings at the park require significant physical improvement to offer decent and comfortable environments for their visitors. Moreover, because the two buildings have not been updated properly, they showed severe conditions in finishes, air ducts, and lighting quality. Because these conditions could be harmful to users of the building, it was urgently needed to assess the current indoor 
environmental quality of the two buildings in the park and develop an improvement plan for those buildings.

After an initial investigation of current conditions of the building and a conversation with the staff, the research team set two main goals for this study: conducting a comprehensive diagnosis of the indoor environmental quality (IEQ) and making a practical recommendation for improving it. To achieve these goals, the research team set specific objectives: They would (1) diagnose current indoor environmental quality through measuring the elements that can affect it, (2) propose an indoor environmental quality improvement plan, and (3) develop an indoor environmental quality assessment checklist that can be utilized in buildings in other state parks. (until here)

\section{Previous Research Relevant to the Topic}

Sustainable design strategies for historic building have been addressed in many previous studies (Grytil, Kvaerness, Rokseth \& Ygre, 2012; Pankhurst \& Harris, 2013, Rostvik, 2013). Grytil, Kvaerness, Rokseth and Ygre (2012) looked at the impact of energy improvement measures on a historic apartment building in Norway. Although there were concerned that energy improvement could destroy the historic values of old building, this research team found that the historic values would be secured even after the energy-saving technologies would be implemented. They conducted several assessments and concluded that implementing energy improvement technologies could reduce the greenhouse gas emission from an old building without reducing its historic integrity. Rostvik (2013) examined an active design using the solar heating system for historic buildings. This research emphasized the use of solar energy for church buildings and post-management in Norway. Once the system was implemented, an appropriate management plan needed to be established. This research also examined the payback periods, which provided empirical evidence for other architects when they implemented this system for old historic churches.

A study for a historic building in a park was conducted by Pankhrst \& Harris (2013). They emphasized sustainable renovation for a visitor center at a park. Their case study described the implementation of photovoltaic slates and panels, geothermal heat pumps, underfloor heating, and the improvement of insulation for the walls and air tightness in a historic park building. Their case study also reported the benefits from the photovoltaic systems to energy saving for a building. Their study showcased the use of various energy-saving techniques for a historic park building.

As these studies presented, sustainable design principles and practices have been implemented in many historic buildings. The major target buildings for the previous studies were residential, commercial, or religious buildings, however. The buildings located in state parks have not been paid enough attention. Because the state parks already provide green outdoor environments for visitors, they would expect the buildings within the parks to provide healthy and green environments. The indoor environment in these buildings should thus be comfortable and appropriately maintained.

Only a few non-scholarly publications are found relevant to the sustainable park building design. One of them was released by the Tennessee State Park (2010). It was a manual to introduce its LEED-certified cabin in one of its state parks. It provided overall green design features applied in a lodge within a park. This manual became a benchmark for many other state parks. Still the scope of its work did not reach to cover the indoor environmental quality in the buildings located in state parks. Because many visitors use the buildings in state parks, the indoor environments in those buildings should be maintained properly.

\section{Research Method}

\subsection{Study Area}

The Cambridge Junction Historic State Park has two early 18th and 19th century buildings that are historically significant to Michigan's transportation history and tourism (Quinn Evans Architects, 2003). The Hewitt House building and Walker Tavern building are those two buildings. They were famous tourist destinations in the 1920s.

After passing through different ownerships for a century, the Michigan Department of Natural Resources purchased the buildings and property in the late 1960s. Although the site and buildings are no longer used for dining or a tourist destination, the park has preserved its historic features. The park is currently maintained jointly by the Michigan Historical Center, Michigan Department of History, Arts and Libraries in the hope of restoring the property to its 1920's appearance. The official document that showed the physical conditions of the buildings is the "Historic Structure Report for the Hewitt House Building and Walker Tavern Building" authored by Quinn Evans Architects (2003). Figure 1 and 2 present the two buildings' floor plans. 

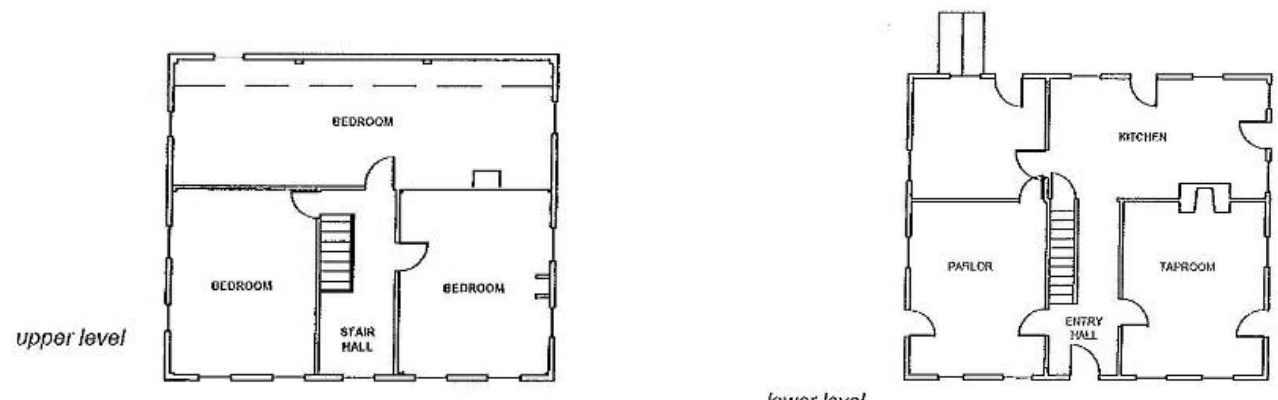

Figure 1. Walker Tavern Building Floor Plans - Down to south (Source: Quinn Evans Architects, 2003, p.21)
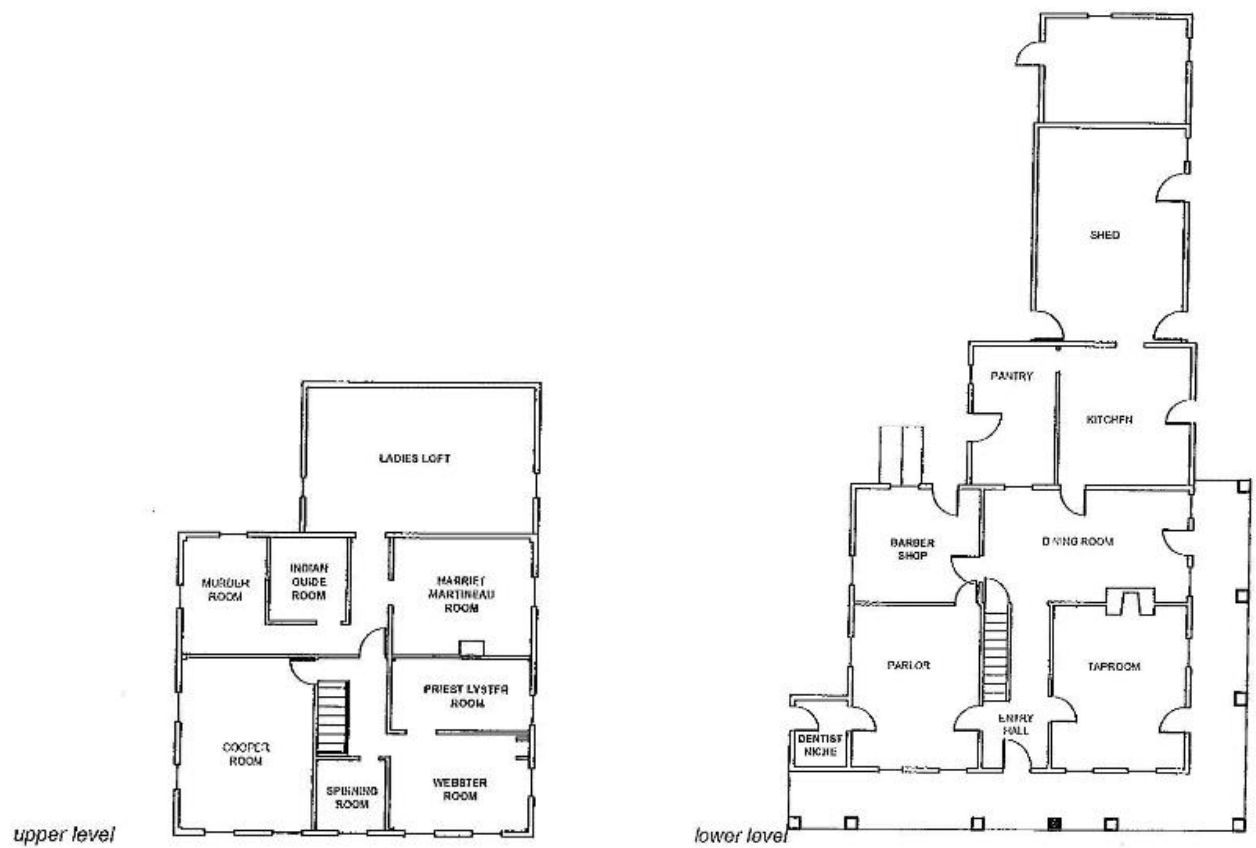

Figure 2. Hewitt House Building Floor Plans, Down to East (Source: Quinn Evans Architects, 2003, p.19)

\subsection{History and Significance of the Buildings}

The report from Quinn Evans Architects (2003) explained that the Walker Tavern building was built in 1832 aiming at serving as a tavern and stagecoach stop. The building was typical homes of this era, the front door entered into a star hall and the ladies' parlor was to the left, and the gentlemen's taproom to the right. In 1843, the tavern was modified to add a wooden porch that spanned the south and east sides of the buildings as well as the addition of a kitchen, a first floor bedroom and two additional bedrooms on the second floor. For 60 years from 1865, a new kitchen, pantry, and an additional small room were added to the existing kitchen. The current interior spaces are presented in table 1.

Hewitt House building was built in 1929 by Fred Hewitt who purchased the property in 1922. His ownership's period (1922-1968), Hewitt tried to maximize the tourist potential of the building and built his own house named the Hewitt House building. Because this building had a residential purpose, the building had a typical plan of a story house, offering common spaces on the first floor and private bedrooms on the second floor. Hewitt continued to own the house in the late 1960's. Shortly afterward the Department of Natural Resources purchased the property (Quinn Evans Architects, 2003). The building still preserves the original layout of the interior spaces, but the first floor is used for the tourists and the DNR staff, which offers an exhibit room, an office, and a conference room, and a dining room. Figure 3 shows these two buildings located in the park. 


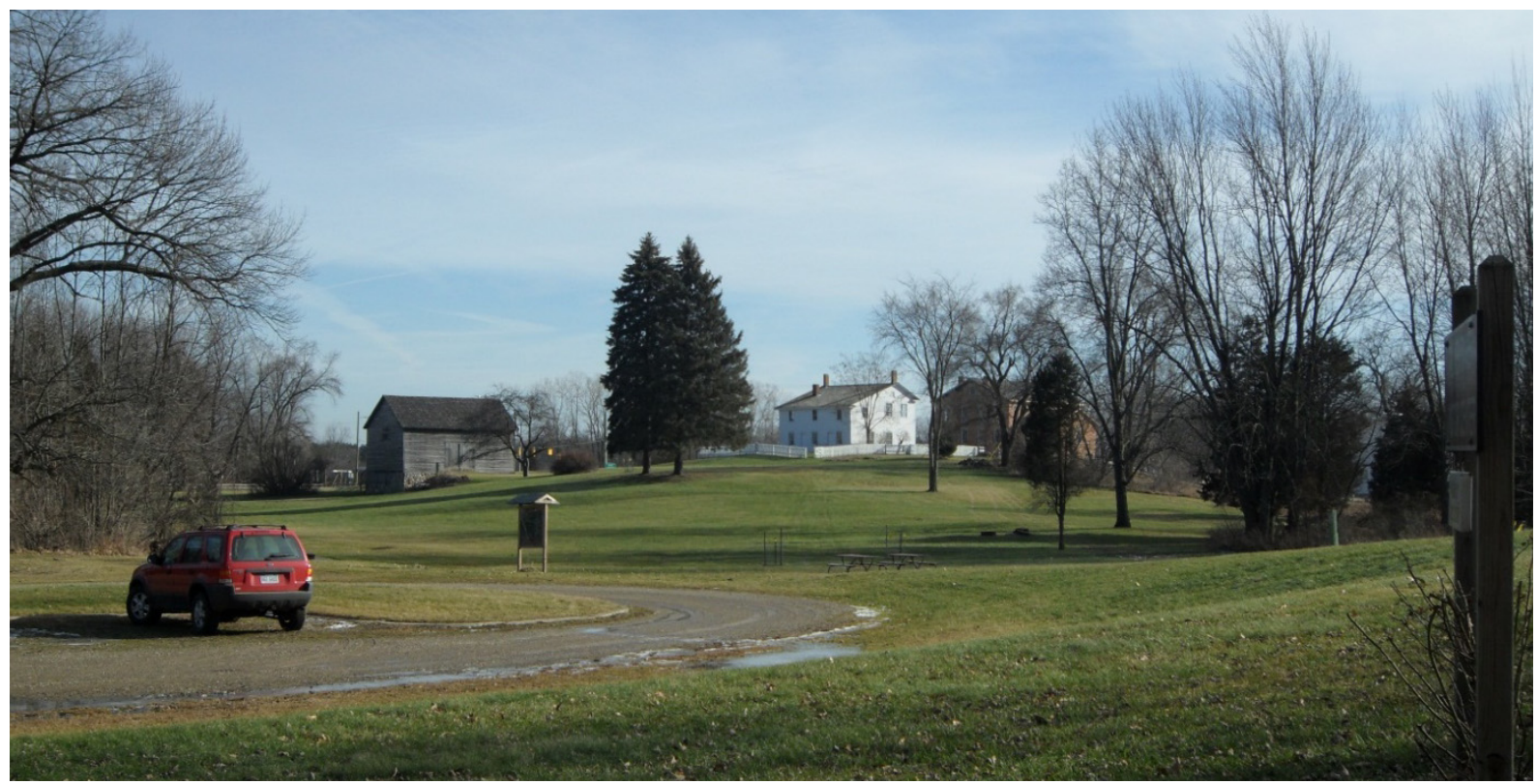

Figure 3. Two building in the Cambridge Junction Historic State Park (Photo credit by the author)

\subsection{Current Status of the Buildings}

The park site and buildings are outdated, but the historic context of the site and buildings is well preserved. The site provides a parking lot and preserves natural habitats and walking paths around the park. The building in the part show historic elements in interior and exterior conditions. The images in the table 1 show the conditions of the two buildings.

Table 1. Current conditions of the Walker Tavern Building and Hewitt House Building

\begin{tabular}{l} 
Items \\
\hline Walker Tavern Building \\
Walker Tavern Building: \\
South facing façade \\
Hewitt House Building: \\
North facing façade \\
Interior Space \\
Walker Tavern Building: \\
Kitchen (upper) \\
Parlor (middle) \\
$2^{\text {nd }}$ floor bedroom (lower)
\end{tabular}


Hewitt House Building:

Office (upper)

Conference room (middle)

Exhibit room (lower)
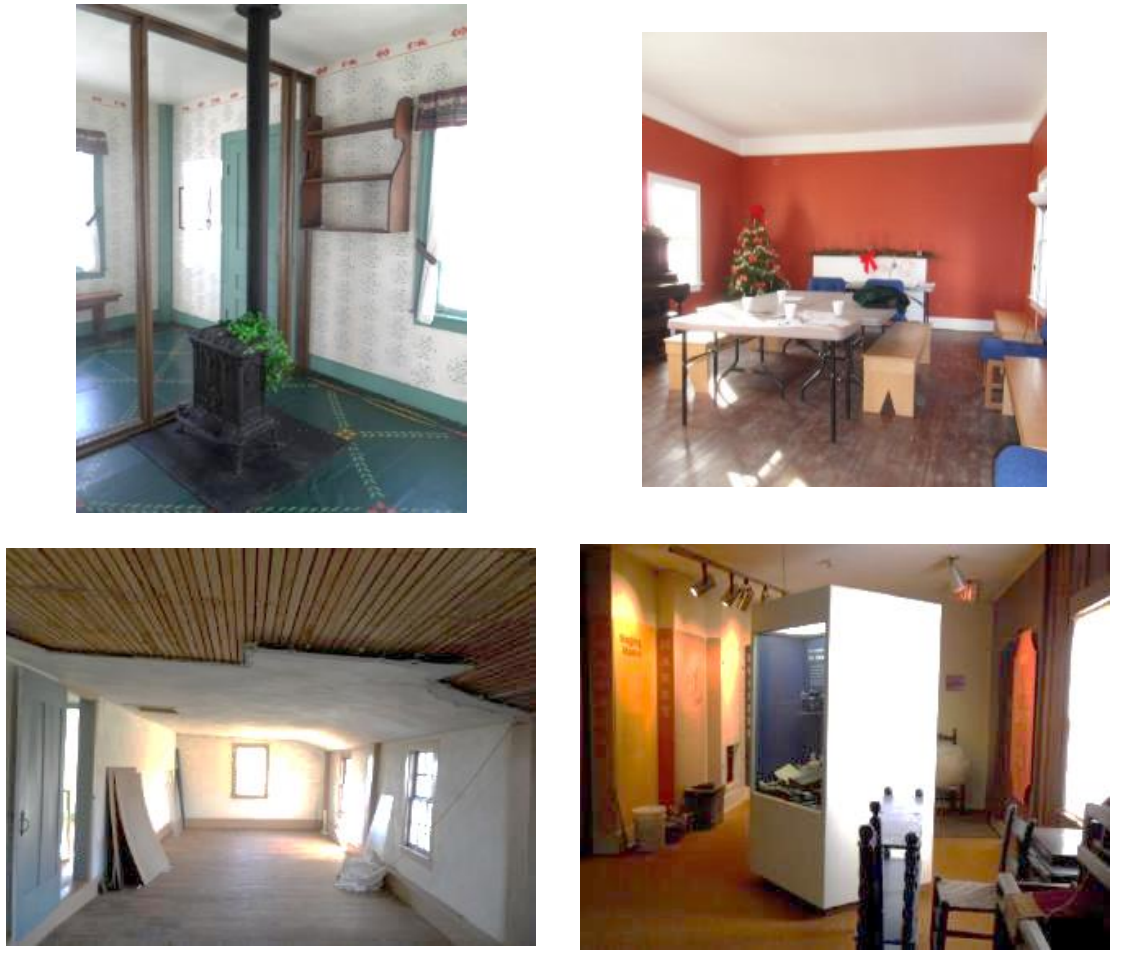

Photo credits by the author

\subsection{Research Process and Methods}

To diagnose indoor environmental quality (IEQ) and make a practical recommendation for improving the IEQ, this research employed an onsite measurement of the indoor environmental features. According to the US Green Building Council's LEED rating systems, the IEQ incorporates four elements into any evaluation of indoor environments: indoor air quality, thermal comport, lighting, and acoustics (US Green Building Council, 2009). The research team developed a checklist to assess these elements. The team initially included the items to measure indoor air quality, indoor temperature, lighting, and acoustics. However, two pilot measurements during the initial phase of the research did not indicate clearly any acoustical issues. The maintenance staff also did not recognize the issue of noise control. Therefore, the measurement of the indoor environmental quality did not include items to check the acoustics.

The first step was to visit the park site and buildings. After the first site visit, the team reviewed literature and sources relevant to historic parks, buildings, and green buildings. The team reviewed research that measured indoor environmental quality of public buildings (e.g., Kim \& Lee, 2014; Lee \& Kim, 2009; USGBC, 2009). The team also consulted five green building experts to confirm the items in the assessment checklist. The five experts had ten or longer years of experience in green building design and management and were LEED Accredited Professionals. The LEED Accredited Professional (LEED AP) is an accredited credential issued by the US Green Building Council for the individuals who have passed the LEED AP tests (USGBC, 2016). Most of the LEED APs have extensive experience in green building design or maintenance. The research followed the process depicted in figure 4 .

Based on the literature review and the experts' input, the team developed an assessment tool presented in table 2 and visited the site twice to measure indoor elemental conditions. The assessment tool for the indoor environmental quality had items for identifying problems in indoor temperature, humidity, and indoor air quality. It also evaluate the following contents of the buildings. 


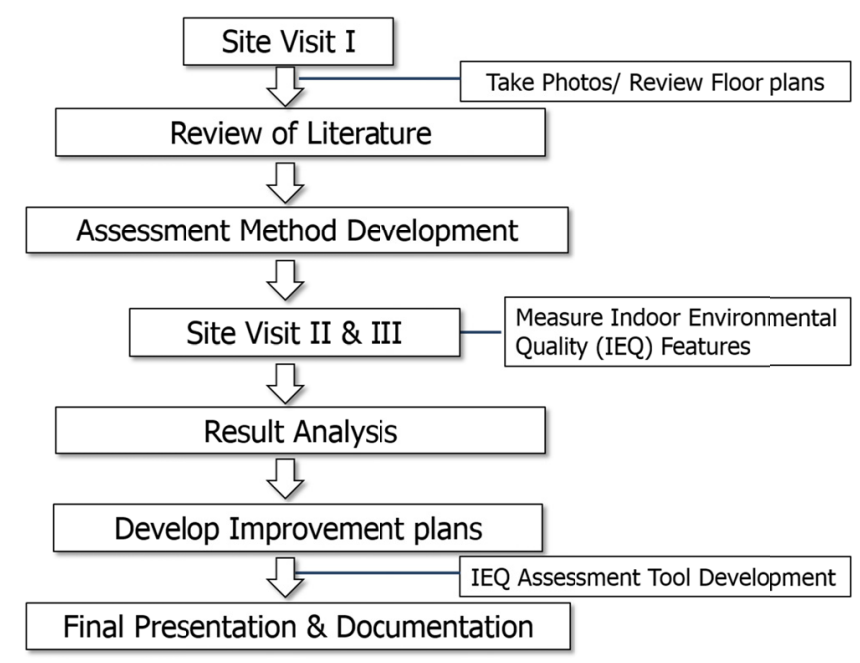

Figure 4. Research process

Table 2. Items in the assessment tool of the indoor environmental quality (IEQ)

\begin{tabular}{|c|c|c|}
\hline Category & Mandatory Items & Additional Items \\
\hline \multirow[t]{2}{*}{ Indoor Air Quality } & $\mathrm{CO}_{2}$ level & $\begin{array}{l}\text { Operable windows: The windows need to be opened } \\
\text { easily. This examines if the space has enough natural } \\
\text { ventilation to keep good indoor air quality. }\end{array}$ \\
\hline & & $\begin{array}{l}\text { Window heights to reach to open: Windows should be } \\
\text { reachable by wheelchair users for natural ventilation }\end{array}$ \\
\hline \multirow[t]{2}{*}{ Thermal Comfort } & Temperature & \multirow{2}{*}{$\begin{array}{l}\text { Individual room temperature control: The room } \\
\text { temperature control can enhance thermal comfort }\end{array}$} \\
\hline & Humidity & \\
\hline \multirow[t]{3}{*}{ Lighting } & Lighting fixture & Individual room lighting control: The individual \\
\hline & Illumination & $\begin{array}{l}\text { lighting control can manage energy saving and enhance } \\
\text { occupant satisfaction with the illumination level of the } \\
\text { spaces. }\end{array}$ \\
\hline & & $\begin{array}{l}\text { Energy efficient bulbs: In addition to providing } \\
\text { sufficient illumination, the bulbs need to be energy } \\
\text { efficient. }\end{array}$ \\
\hline \multirow[t]{3}{*}{ Other } & Orientation of the building & $\begin{array}{l}\text { Check orientation of the building: This will show the } \\
\text { available daylight for the spaces. }\end{array}$ \\
\hline & & Check the maintenance conditions of ducts and vents \\
\hline & & Check walls and attics for insulation \\
\hline
\end{tabular}

Note: The items in table 2 were excerpted from USGBC (2009)

The measurement results were analyed and discussed with the Michigan Department of Natural Resources. Finally, the research team recommended an improvement proposal for the two buildings. The major recommendations were reiewed and used by the DNR staff and researchers.

\section{Findings and Discussion}

\subsection{Indoor Air Quality and Thermal Condition}

All rooms of two buildings were numbered and their $\mathrm{CO}_{2}$, temperature, and humidity were measured two hours and the averages are presented in table 3 . 
Table 3. Indoor environmental quality result

\begin{tabular}{|c|c|c|c|c|c|c|c|}
\hline Building & Floor & Space & $\begin{array}{l}\text { Temperature } \\
\text { (Fahrenheit) }\end{array}$ & $\begin{array}{c}\text { Humidity } \\
(\%)\end{array}$ & $\begin{array}{c}\mathrm{CO}_{2} \\
(\mathrm{ppm})\end{array}$ & $\begin{array}{c}\text { Ventilation } \\
\text { rate } \\
(\mathrm{cfm} / \mathrm{p})\end{array}$ & $\begin{array}{c}\text { No. of } \\
\text { occupant } \\
\text { during } \\
\text { measurement }\end{array}$ \\
\hline \multirow{7}{*}{$\begin{array}{l}\text { Walker } \\
\text { Tavern } \\
\text { Building }\end{array}$} & 1 & 1-Taproom & 46.9 & 40.3 & 437 & 200 & 3 \\
\hline & 1 & 2-Parlor & 47.6 & 36.8 & 434 & 200 & 4 \\
\hline & 1 & 3-Kitchen & 46.5 & 43.3 & 415 & 200 & 4 \\
\hline & 1 & 4-Personal Room & 49 & 32.4 & 348 & 200 & 4 \\
\hline & 2 & 5-Bedroom & 48.5 & 48.8 & 864 & 22.8 & 4 \\
\hline & 2 & 6-Bedroom & 46.8 & 46.2 & 725 & 68.2 & 4 \\
\hline & 2 & 7-Bedroom & 49.2 & 47.5 & 631 & 45.5 & 4 \\
\hline \multirow{11}{*}{$\begin{array}{l}\text { Hewitt } \\
\text { House } \\
\text { Building }\end{array}$} & 1 & 1-Conference room & 71.6 & 34.6 & 932 & 15 & 8 \\
\hline & 1 & 2-Dining room \& hall & 73.6 & 30.3 & 718 & 17 & 5 \\
\hline & 1 & 3-Exhibit space & 73.8 & 30.8 & 654 & 41.4 & 4 \\
\hline & 1 & 4-Bathroom & 73.8 & 29.3 & 705 & 34.4 & 1 \\
\hline & 1 & 5-Office & 74.3 & 29.7 & 675 & 38.1 & 3 \\
\hline & 1 & 6-Reception area & 75.4 & 31.4 & 873 & 22.5 & 5 \\
\hline & 2 & 7-Storage 1 & 73.1 & 30.3 & 909 & 21.2 & 2 \\
\hline & 2 & 8 -Storage 2 & 73.3 & 30.2 & 788 & 27.1 & 2 \\
\hline & 2 & 9-Storage 3 & 72.8 & 31.9 & 785 & 27.2 & 2 \\
\hline & 2 & 10-Storage 4 & 71.9 & 32.6 & 812 & 26.1 & 2 \\
\hline & 2 & 11-Stair hall & 72.5 & 31.0 & 720 & 28.6 & 4 \\
\hline
\end{tabular}

The Hewitt House building was heated during the visit, so the rooms' temperatures were higher than those in Walker Tavern building. Because its heat was on, the Hewitt House building had drier indoor environments than those in the Walker Tavern building. The $\mathrm{CO}_{2}$ levels in the rooms in both buildings varied. In Walker Tavern building its levels ranged from 348 to $864 \mathrm{ppm}$. In Hewitt House building, its levels ranged from 654 to $932 \mathrm{ppm}$. One factor in the difference is that the Hewitt House building had more visitors than Walker Tavern building during the operation hours.

Because ventilation could affect indoor air quality, it was measured. As table 3 presents, the Hewitt House building provided stable levels of ventilation ranging from 15 to $41.4 \mathrm{ppm}$ compared to those in Walker Tavern building that showed a bigger variation range. In the Walker Tavern building, cracks between window frames and walls brought in outside air. The windows were single layers and have not been replaced since the 1960s. This made it difficult to regulate the room temperature and ventilation to provide comfortable indoor environments for visitors. Figures 5 and 6 show these conditions of the rooms in the Walker Tavern building.

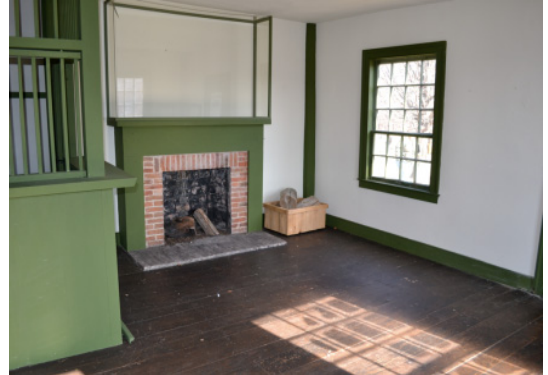

Figure 5. Taproom in the Tavern

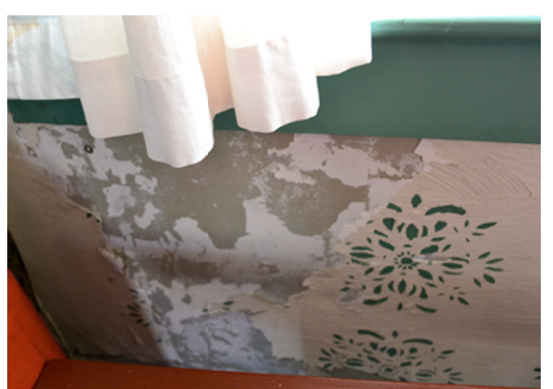

Figure 6. Unfinished wall in the Tavern 
The Hewitt House building had better indoor environments. Yet, its exhibition space had lower temperatures and cold air flows because its outdated ducts and vent systems blocked the flow of warm air. There was either no or very thin insulation inside the walls and attics. Figure 7 through 12 show these problems of the spaces. These problems severely compromised the indoor environmental quality. Therefore, the research team proposed solutions to these problems in its future improvement plan.

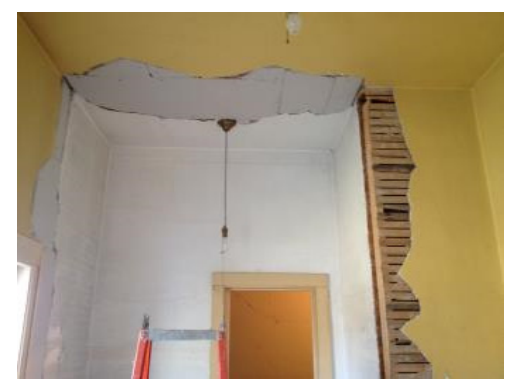

Figure 7. Wall and ceiling in the exhibit room corner

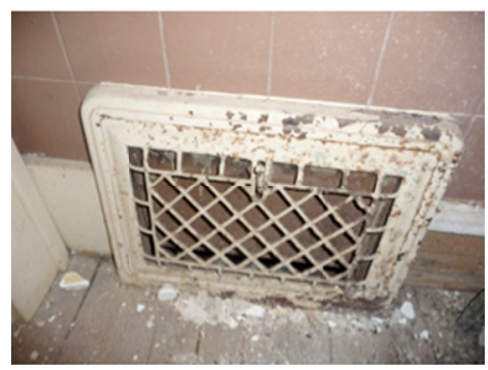

Figure 10. Unmaintained vent to be replaced

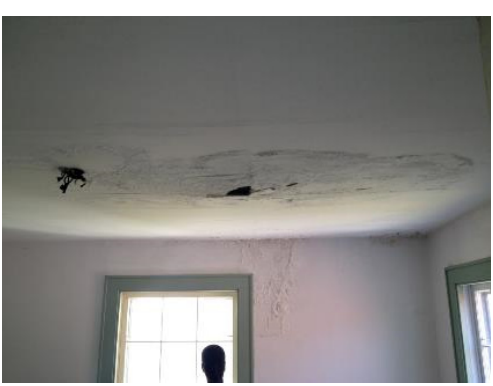

Figure 8. Cracked ceiling in the storage space

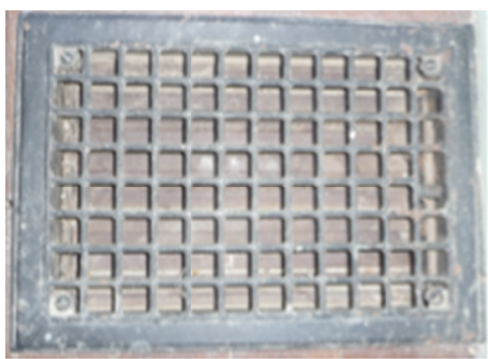

Figure 11. Improperly covered vent

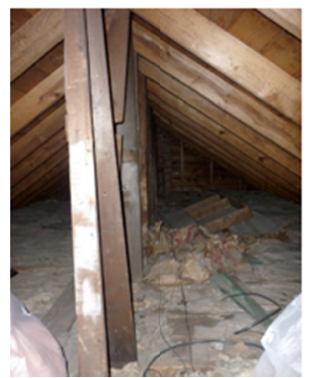

Figure 9. Attic insulation

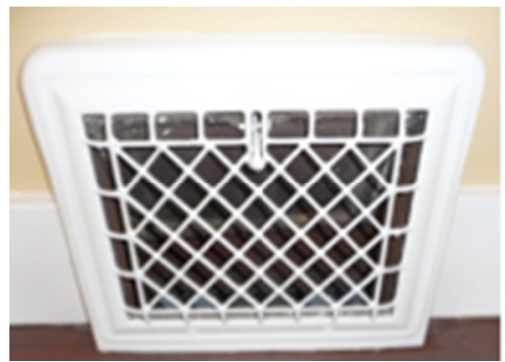

Figure 12. Updated vent

\subsection{Lighting and Daylight}

The lighting fixtures of the two buildings were outdated or not properly replaced. The illumination levels were measured twice and the averages are presented in table 4.

Table 4. Lighting fixtures and illumination levels

\begin{tabular}{lllccc}
\hline \multicolumn{1}{c}{ Building } & Floor & \multicolumn{1}{c}{ Space } & $\begin{array}{c}\text { Lighting } \\
\text { fixture }\end{array}$ & $\begin{array}{c}\text { Number of } \\
\text { windows }\end{array}$ & $\begin{array}{c}\text { Illumination } \\
\text { (footcandle) }\end{array}$ \\
\hline Walker & 1 & 1-Taproom & 1 & 3 & 181 \\
Tavern & 1 & 2-Parlor & 1 & 3 & 90 \\
Building & 1 & 3-Kitchen & 2 & 5 & 13.5 \\
& 1 & 4-Personal Room & 1 & 2 & 25.9 \\
& 2 & 5-Bedroom & 1 & 4 & 245 \\
& 2 & 6-Bedroom & 1 & 1 & 185 \\
Hewitt House & 2 & 7-Bedroom & 2 & 3 & 23.5 \\
Building & 1 & 1-Conference room & 0 & 3 & 45 \\
& 1 & 2-Dining room \& hall & 0 & 2 & 16 \\
& 1 & 3-Exhibit space & 11 & 1 & 62 \\
& 1 & 4-Bathroom & 0 & 1 & 17.2 \\
& 1 & 5-Office & 1 & 1 & 25 \\
& 1 & 6-Reception area & 2 & 1 & 19.1 \\
& 2 & 7-Storage 1 & 1 & 2 & 23.6 \\
& 2 & 8-Storage 2 & 1 & 1 & 0.2 \\
& 2 & 9-Storage 3 & 1 & 2 & 47 \\
& 2 & 10-Storage 4 & 2 & 1 & 50.5 \\
\hline
\end{tabular}


In the Walker Tavern building, the kitchen had some windows but their placement in relation to the position of the sun did not provide adequate lighting. Other rooms in the Walker Tavern building did not provide appropriate bulbs. The rooms had windows to admit natural light. Illumination in the Hewitt House building was less when the lights were turned off. Most spaces did not provide adequate lighting for certain tasks. Lighting was identified as a serious problem that needed improvement.

\subsection{Other Elements that Affect Indoor Environments}

\subsubsection{Building Orientation}

The orientations of the buildings can affect illumination and temperature controls of the buildings (USGBC, 2011). The main entrance of the target buildings faced south. The longer exterior walls also faced south, which could admit more daylight to the interior spaces. Figures 13 and 14 show the buildings' exteriors that take daylight. The future improvement plan should maximize these advantages.

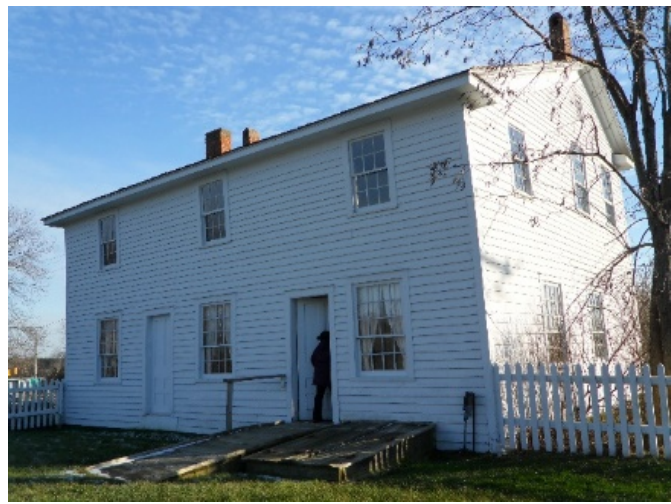

Figure 13. Walker Tavern Building Façade

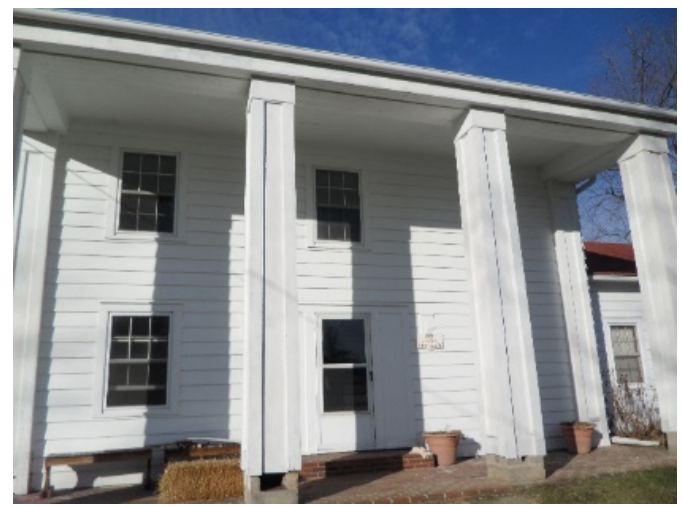

Figure 14. Hewitt House Building Façade

\subsubsection{Operable Windows}

Operable windows can admit fresh air from outside (USGBC, 2011). Operable windows can also help to control indoor temperature and humidity. All windows in the two building were checked to see if they could be opened easily. None of the windows in Walker Tavern building were easy to open. Some were sealed shut. The windows in this building still had their original shapes and finishes. They have not been updated for several decades. Therefore, the windows did not function properly for the purpose of ventilation.

Unlike those in the Walker Tavern building, most of the windows in the Hewitt House building could be opened and closed, but only with difficulty. Some window frames of this building had been repainted or remounted. Therefore, they could be used for ventilation purpose. Yet, the windows needed strong forces to be pushed or pulled to open and close. Figures 15 and 16 show the windows in these two buildings. Although the windows were not easy to use, they still let plenty of daylight into the buildings. This natural light improved the indoor environmental quality of the buildings.

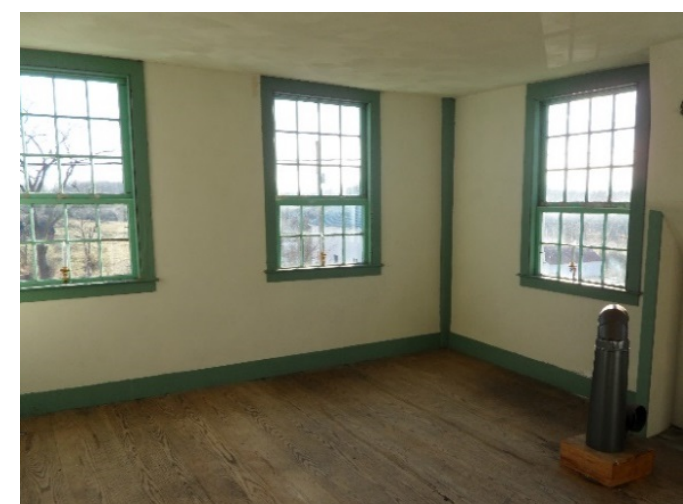

Figure 15. Windows in Walker Tavern Building

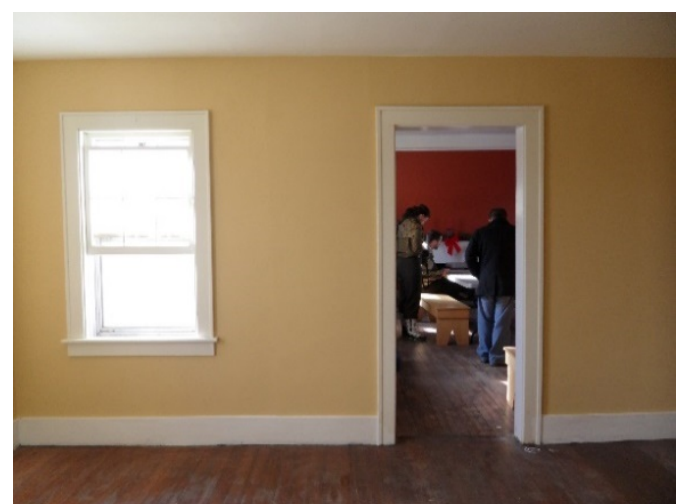

Figure 16. Window in Hewitt House Building 


\subsubsection{Window Heights from the Floor}

To evaluate the windows' operation capabilities, the research team measured the heights of the inside mounts of all windows from floors to see if wheelchair users could open and close them. As mentioned previously, operable windows can improve a building's indoor environmental quality. The standards for the window heights were based on the American with Disabilities Act (ADA) Standards for Accessibility Design by the Civil Rights Division of the US Department of Justice (2010).

In Walker Tavern building the distance from the floor to the window aprons ranged from $231 / 2$ inches to $441 / 2$ inches. This meant that wheelchair users could access them. However, the windows were sealed shut, so they were not operable. The windows in Hewitt House building were also of appropriate heights, ranging from 23 inches to 25 inches.

ADA guidelines state that operable parts of a window shall be operable with one hand and shall not require tight grasping, pinching, or twisting of the wrist (Civil Rights Division, 2010). The force required to operate a window shall be 5 pounds maximum. The current windows in these two buildings were reachable but did not meet the ADA guidelines for the operation. Due to this reason, they could not be used as a source of natural ventilation for the buildings.

\subsection{Discussion about the Indoor Environmental Quality}

This study focused on several elements to affect indoor environmental quality (IEQ) of the historic buildings housed in a state park. Those elements were identified based on the literature review and the US Green Building Council's four elements contributing toward IEQ. Considering the limited functions of the buildings currently, the research team focused on $\mathrm{CO}_{2}$, temperature, humidity, and illumination levels in indoor spaces. Because most lighting fixtures have not been properly updated, a further analysis regarding the illumination levels will not be provided in this paper.

The levels of $\mathrm{CO}_{2}$, temperature, and humidity were compared to the American Society of Heating, Refrigerating, and Air Conditioning Engineers (ASHRAE) (2013). Table 5 presents these comparisons. The temperatures in the Walker Tavern building's interior spaces did not meet the ASHRAE standards, but humidity and $\mathrm{CO}_{2}$ levels in the room did.

Table 5. Comparison of indoor environmental conditions between in the target buildings and the ASHRAE standards

\begin{tabular}{|c|c|c|c|c|c|c|c|c|}
\hline Building & Floor & Space & $\begin{array}{c}\text { Temp. } \\
\left(\mathrm{F}^{\circ}\right)\end{array}$ & $\begin{array}{c}\text { Humidity } \\
(\%)\end{array}$ & $\begin{array}{c}\mathrm{CO}_{2} \\
(\mathrm{ppm})\end{array}$ & $\begin{array}{c}\text { ASHRAE } \\
\text { Temperature }\end{array}$ & $\begin{array}{l}\text { ASHRAE } \\
\text { Humidity }\end{array}$ & $\begin{array}{c}\text { ASHRAE } \\
\mathrm{CO}_{2}\end{array}$ \\
\hline Walker & 1 & 1-Taproom & 46.9 & 40.3 & 437 & $67-82$ & $30-60 \%$ & 1,000 \\
\hline Tavern & 1 & 2-Parlor & 47.6 & 36.8 & 434 & & & ppm \\
\hline \multirow[t]{5}{*}{ Building } & 1 & 3-Kitchen & 46.5 & 43.3 & 415 & & & \\
\hline & 1 & 4-Personal Room & 49 & 32.4 & 348 & & & \\
\hline & 2 & 5-Bedroom & 48.5 & 48.8 & 864 & & & \\
\hline & 2 & 6-Bedroom & 46.8 & 46.2 & 725 & & & \\
\hline & 2 & 7-Bedroom & 49.2 & 47.5 & 631 & & & \\
\hline $\begin{array}{l}\text { Hewitt } \\
\text { House }\end{array}$ & 1 & $\begin{array}{l}\text { 1-Conference } \\
\text { room }\end{array}$ & 71.6 & 34.6 & 932 & $67-82$ & $30-60 \%$ & $\begin{array}{l}1,000 \\
\text { ppm }\end{array}$ \\
\hline \multirow[t]{10}{*}{ Building } & 1 & $\begin{array}{l}\text { 2-Dining room \& } \\
\text { hall }\end{array}$ & 73.6 & 30.3 & 718 & & & \\
\hline & 1 & 3-Exhibit space & 73.8 & 30.8 & 654 & & & \\
\hline & 1 & 4-Bathroom & 73.8 & 29.3 & 705 & & & \\
\hline & 1 & 5-Office & 74.3 & 29.7 & 675 & & & \\
\hline & 1 & 6-Reception area & 75.4 & 31.4 & 873 & & & \\
\hline & 2 & 7-Storage 1 & 73.1 & 30.3 & 909 & & & \\
\hline & 2 & 8 -Storage 2 & 73.3 & 30.2 & 788 & & & \\
\hline & 2 & 9-Storage 3 & 72.8 & 31.9 & 785 & & & \\
\hline & 2 & 10 -Storage 4 & 71.9 & 32.6 & 812 & & & \\
\hline & 2 & 11-Stair hall & 72.5 & 31.0 & 720 & & & \\
\hline
\end{tabular}

Note: ASHRAE 2013 was referred to for this comparison table. 
In the Hewitt House building, indoor temperatures met the standards, but the humidity in several spaces were below ASHRAE standards. Those spaces were the first floor office for the staff and the bathroom where their indoor temperatures were slightly higher than other spaces. The fact that the indoor spaces with higher temperatures had lower humidity indicated that the indoor environmental quality of these buildings was not being maintained appropriately.

\subsection{Indoor Environmental Quality Assessment Tool Development}

This study focused on two historic buildings located in a state park. From this case study, the research team proposed an assessment tool that can briefly check indoor environmental quality in the old buildings in state parks. The research team labeled this tool as "Indoor environmental quality quick assessment tool for state park buildings." Table 6 presents the items to be measured and descriptions of the measurement methods.

The tool includes measuring temperature, humidity, and indoor air quality of individual spaces. The assessment tool also checks lighting fixtures, illumination, and energy-efficiency of the fixtures. The window features, such as orientations, heights, widths, and operability, will be assessed. The conditions of interior finishes and wall and attic insulations are also included in the assessment tool. Lastly the air ducts and vents will be checked to assess the maintenance and cleanness. Based on assessing these conditions using this assessment tool, an improvement plan for any park building's indoor environmental quality could be initiated.

Table 6. Indoor environmental quality primary assessment tool to historic park buildings

\begin{tabular}{|c|c|c|c|c|c|c|}
\hline Category & \multicolumn{5}{|c|}{ Items and description about measurements } & Note \\
\hline \multirow[t]{2}{*}{$\begin{array}{l}\text { Indoor } \\
\text { Environmental } \\
\text { Quality }\end{array}$} & \multicolumn{5}{|c|}{$\begin{array}{l}\text { - Measure indoor air quality and temperature in every space and } \\
\text { identify problems in temperature, humidity, indoor air quality } \\
\left(\mathrm{CO}_{2} \text { level }\right)\end{array}$} & \\
\hline & \multicolumn{5}{|c|}{ - Bring a laptop and install the program and create a table } & \\
\hline \multirow{4}{*}{$\begin{array}{l}\text { Example table of } \\
\text { the IAQ and } \\
\text { thermal condition }\end{array}$} & $\begin{array}{l}\text { Floor } \\
\text { Level }\end{array}$ & Space & $\begin{array}{l}\text { Temperature } \\
\text { (Time) }\end{array}$ & $\begin{array}{l}\text { Humidity } \\
\text { (Time) }\end{array}$ & $\mathrm{CO}_{2}$ (Time) & \\
\hline & 1 & $\begin{array}{l}\text { Conference } \\
\text { room }\end{array}$ & $\begin{array}{l}82 \mathrm{~F} \\
(11: 30 \mathrm{am})\end{array}$ & $\begin{array}{l}36 \% \\
(11: 30 \mathrm{am})\end{array}$ & $\begin{array}{l}900 \mathrm{ppm} \\
(11: 30 \mathrm{am})\end{array}$ & \multirow{3}{*}{$\begin{array}{l}\text { Measuring } \\
\text { Temperature, } \\
\text { humidity, and } \mathrm{CO}_{2}\end{array}$} \\
\hline & 1 & Office & $\begin{array}{l}82 \mathrm{~F} \\
(11: 30 \mathrm{am})\end{array}$ & $\begin{array}{l}36 \% \\
(11: 30 \mathrm{am})\end{array}$ & $\begin{array}{l}900 \text { ppm } \\
\text { (11:30 am) }\end{array}$ & \\
\hline & 1 & $\begin{array}{l}\text { Exhibit } \\
\text { room }\end{array}$ & $\begin{array}{l}82 \mathrm{~F} \\
(11: 30 \mathrm{am})\end{array}$ & $\begin{array}{l}36 \% \\
(11: 30 \mathrm{am})\end{array}$ & $\begin{array}{l}900 \text { ppm } \\
(11: 30 \mathrm{am})\end{array}$ & \\
\hline \multirow[t]{5}{*}{$\begin{array}{l}\text { Example table of } \\
\text { lighting condition }\end{array}$} & \multicolumn{5}{|c|}{$\begin{array}{l}\text { - Check lighting fixtures and measure illumination of each space: } \\
\text { Lighting fixture examples can be fluorescent, incandescent, or } \\
\text { LED bulbs, ceiling fan, wall sconce, wall mount, and so on. }\end{array}$} & \\
\hline & $\begin{array}{l}\text { Floor } \\
\text { Level }\end{array}$ & Space & $\begin{array}{l}\text { Lighting } \\
\text { Fixture }\end{array}$ & $\begin{array}{l}\text { Illuminatio } \\
\mathrm{n} \text { (Time) }\end{array}$ & Note & \\
\hline & 1 & $\begin{array}{l}\text { Conference } \\
\text { room }\end{array}$ & 4 fluorescent & $\begin{array}{l}120 \\
\text { footcandles } \\
(11: 30 \mathrm{am})\end{array}$ & $\begin{array}{l}\text { Energy-effi } \\
\text { cient }\end{array}$ & Measuring \\
\hline & 1 & Office & 4 fluorescent & $\begin{array}{l}120 \\
\text { footcandles } \\
(11: 30 \mathrm{am})\end{array}$ & $\begin{array}{l}\text { Energy-effi } \\
\text { cient }\end{array}$ & \\
\hline & 1 & $\begin{array}{l}\text { Exhibit } \\
\text { room }\end{array}$ & 4 fluorescent & $\begin{array}{l}120 \\
\text { footcandles } \\
(11: 30 \mathrm{am})\end{array}$ & $\begin{array}{l}\text { Energy-effi } \\
\text { cient }\end{array}$ & \\
\hline
\end{tabular}


Other items relevant to indoor environmental quality
- Check orientation of the building: this will show the available daylight for spaces
- Check windows: Are the windows easy to open and close? This will examine if the space can have natural ventilations to keep good indoor air quality.

- Check interior finishes and materials: Check if the materials and finishes have been updated since the building was built. Suggest environmentally-friendly, recycled, or reclaimed materials having similar colors and textures to reduce any issues relevant to VOCs: Take pictures of these details and make tables.

- Find out if this building is insulated

- Check current conditions of air ducts and vents.

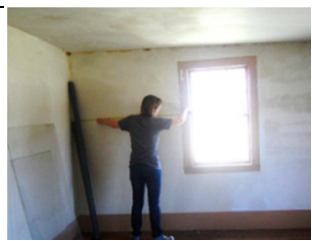

Measuring window location and the distance from the floor

\section{Suggestions and Conclusion}

\subsection{Significance of Indoor Environmental Quality Assessment in Park Buildings}

The state parks in Michigan provide many outdoor attractions, so they have been popular destinations for many tourists. The buildings located in these parks had a variety of functions, for instance as a showcase for the park's history, relaxing, and a place for dining. Some parks have lodges in the middle of the park in addition to spaces for conferences and training sessions. It is reported in 2011 that approximately 22 million people visited Michigan state parks (O’Neil, 2011).

Therefore, the indoor spaces of state park buildings have been serving many different users thus far. It is significant to maintain the indoor environment of these park buildings to keep it comfortable and healthy. This study targeted one of the state parks in Michigan and assessed the current conditions of the buildings in terms of their indoor environmental quality.

The findings of this study proposed three main suggestions. First, the buildings and interior spaces in the state parks need to be maintained and updated properly for visitors and employees. The research team observed the lack of attention to the building and interior space maintenance from this case study although the building had full time staff members. Because indoor environmental quality (IEQ) can affect the occupant's health and comfort, four aspects in IEQ that are temperature, humidity, lighting, and indoor air quality need to be considered.

Second, the indoor environmental quality of the buildings needs to be assessed regularly and improved for space users. Due to the limited budget for the building operation, the quality of the indoor environment did not get enough attention from the DNR and the state government. However, some elements that negatively affect indoor environmental quality were identified from this study. Lack of natural ventilation due to the unmaintained vents, low indoor temperature due to the lack of wall and attic insulation, and absence of lighting fixtures are those examples. To generalize this need, research targets need to be extended to other buildings in state parks and more cases needs to be investigated.

Third, the indoor environmental quality assessment tool was proposed based on this case study in one of the state parks in Michigan. The tool includes key items to measure the IEQ of the buildings in state parks and the descriptions to show how to measure those items. This tool can be used in other state park buildings to measure the IEQ and identify the problems relevant to their indoor environments.

\subsection{Continuous Efforts for Retrofitting Park Buildings}

The research findings reported actual indoor environment conditions of the Hewitt House building and Walker Tavern building in the Cambridge Junction Historic State Park. The Michigan State Department of Natural Resources was informed the suggestions from the research. The Hewitt House building had conducted several minor upgrades before this indoor environmental quality assessment study was conducted. In 2015, the building retrofit was completed (Cherry, 2015). Currently the State Park site of this study offers various historic displays and summer activities in the updated environment.

\subsection{Limitation of the Study and the Suggestion for the Comprehensive Plan}

This research has a limitation in generalization of the findings, however. The research team targeted the buildings in one state park. Although these research targets were identified by the DNR and results represented 
the problems in IEQ of park buildings, other state parks could have been maintained properly to provide better indoor environmental quality condition.

The DNR manages the park planning and maintenance, but each park has been run independently by the staff members who are affiliated with their own parks. Therefore, each state park has buildings in different conditions. This fact brought a strong need for developing a comprehensive plan for the buildings in state parks. DNR has established common goals for park planning, but a comprehensive plan for maintaining and upgrading the buildings in the state parks has not been implemented well. To project a long-term vision for the sustainable park buildings, a comprehensive plan for embracing entire state parks and buildings needs to be developed. Based on this plan, individual parks can take the advanced steps to promote or upgrade their parks to serve the needs of visitors, employees, and local communities.

Despite this limitation, the results and suggestions from this case study can be employed by the researchers who will attempt evaluating the buildings in any state parks and identify the problems in the indoor environmental quality of such buildings. In fact, the tool was utilized later in assessing the indoor environmental quality of several buildings in other state parks in Michigan.

\section{Acknowledgement}

The author specially thank Dan Lord and Mary Nardo in the Michigan Department of Natural Resources and Monica Day at Michigan State University Extension for this project. The author also thanks Brittany Bachteal, Allison Good, Amanda Karaba, Jamie Kempera, Sherri Lawrence, Hannah Lukasiewicz, Katie Munks, Kali Pervolarakis, Rosalyn Rogers, Erica Shepard, Katlyn Swetland, Ayssa Vernad, and Stephanie Space for their participation in the data collection process. The author truly appreciates the continuous partnership with the DNR, which has enhanced students' learning experiences and outcomes.

\section{References}

American Society of Heating, Ventilation, Air-conditioning and Refrigeration. (2016). ASHRAE Technical FAQ from the ASHRAE Standard 55-2013, Thermal Environmental Conditions for Human Occupancy. Retrieved June 1, 2016, from https://www.ashrae.org/File\%20Library/docLib/Technology/FAQs2014/TC-02-01-FAQ-92.pdf

Cherry, D. (2015). 3-year H House renovation project nears completion. Retrieved August 20, 2017, from http://www.lenconnect.com/article/20150419/NEWS/150419030

Civil Rights Division of the US Department of Justice. (2010). ADA (American with Disabilities Act) Standards for Accessibility Design. Retrieved September 1, 2016, from https://www.ada.gov/2010ADAstandards_index.htm

Grytli, E., Kværness, L., Rokseth, L., \& Ygre, K. (2012). The impact of energy improvement measures on heritage buildings. Journal of Architectural Conservation, 18(3), 89-106. https://doi.org/10.1080/13556207.2012.10785120

Kim, S. K. (2012). A universal and green design proposal for Michigan park buildings: Accessibility, energy-efficiency, \& indoor environmental quality assessment of MI park buildings in Cambridge Junction Historic State Park. June 2012. Unpublished Report for the Department of Natural Resources.

Kim, S. K., \& Lee, E. S. (2014). LEED for Homes Rating System and resident satisfaction with LEED-certified homes: Focusing on the US cases. Journal of Korean Housing, 25(3), 25-34. https://doi.org/10.6107/JKHA.2014.25.3.025

Lee, Y. S., \& Kim, S. K. (2008). Indoor environmental quality in LEED-certified buildings in the U.S. Journal of Asian Architecture and Building Engineering, 7(2), 293-300. https://doi.org/10.3130/jaabe.7.293

O’Neil, S. (2011). Recent recognition as the nation's best park system has Michigan officials hoping for a boost in tourism. Retrieved July 30, 2017, from http://news.jrn.msu.edu/capitalnewsservice/2011/11/11/recent-recognition-as-the-nation\%E2\%80\%99s-best -park-system-has-michigan-officials-hoping-for-a-boost-in-tourism/

Pankhurst, C., \& Harris, A. (2013) Conservation and innovation: The challenge of 'eco' renovation in heritage $\begin{array}{lllll}\text { buildings. Journal of Architectural } & \text { Conservation, } & 19(1), & \text { 18-34. }\end{array}$ https://doi.org/10.1080/13556207.2013.787017

Røstvik, H. (2013). Listed church buildings and solar energy. Journal of Architectural Conservation, 19(1), 49-67. https://doi.org/10.1080/13556207.2013.787019 
Quinn Evans Architects. (2003). Historic structure report: Hewitt House and Walker Tavern building. Ann Arbor, MI: Quinn Evans Architects.

Tenessee Department of Environmen and Conservation. (2010). David Crokett State Park: Green cabin education manual. Retrieved June 1, 2015, from http://nstateparks.com/parks/cabins/david-crockett

U.S. Green Building Council. (2009). LEED Green Associate Study Guide. Washington, DC: U.S. Green Building Council.

U.S. Green Building Council. (2009). Green Building and LEED Core Concepts. Washington, DC: U.S. Green Building Council.

\section{Copyrights}

Copyright for this article is retained by the author(s), with first publication rights granted to the journal.

This is an open-access article distributed under the terms and conditions of the Creative Commons Attribution license (http://creativecommons.org/licenses/by/4.0/). 